\title{
Screening of Root Traits in Maize (Zea mays L.) Landraces in Relation to Drought Stress
}

\author{
Sapna $^{1}$, Z. A. Dar ${ }^{2 *}$, Sherry Jacob ${ }^{1}$, A. A. Lone ${ }^{2}$ and F. Rasool ${ }^{2}$ \\ ${ }^{1}$ ICAR-National Bureau of Plant Genetic Resources, Pusa Campus, \\ New Delhi 110012, India \\ ${ }^{2}$ Dryland Agriculture Research Station, SKUAST, Kashmir-190001, India \\ *Corresponding author
}

\section{A B S T R A C T}

\begin{tabular}{|l|}
\hline Ke y w o r d s \\
Root traits, \\
Maize, Landraces, \\
$\begin{array}{l}\text { Drought stress, } \\
\text { Root biomass }\end{array}$ \\
\hline Article Info \\
\hline $\begin{array}{l}\text { Accepted: } \\
26 \text { April } 2020 \\
\text { Available Online: } \\
\text { 10 May } 2020\end{array}$ \\
\hline
\end{tabular}

Present investigation was planned to screen thirty maize landraces for root traits in relation to drought tolerance. Drought stress is one of the most important abiotic stress which reduces growth, development and yield of the plants. Developing maize cultivars that can perform well in drought and other abiotic stresses is an important goal throughout the world. Rooting depth was highest in SRG $9(47 \mathrm{~cm})$ and lowest in SRG $5(14 \mathrm{~cm})$ under drought condition. Root volume was highest in SRG9, SRG 10, SRG 12, SRG 19 and SRG 26 while lowest in SRG5 under drought conditions. The relative proportion of root biomass allocation to the top and bottom zones reveals that highest proportion of roots at bottom under drought was for SRG $21(5 \mathrm{~g})$ while as lowest for SRG $21(0.2 \mathrm{~g})$. Similarly root biomass in top portion was highest under drought for SRG 21 (9 g) and lowest in SRG $7(1.1 \mathrm{~g})$.

\section{Introduction}

Maize (Zea mays L.) is currently produced on nearly 100 million hectares in 125 developing countries and is among the three most widely grown crops in 75 of those countries (FAOSTAT, 2010). By 2050, the demand for maize in the developing world will double and in next ten years maize production is expected to be highest globally, especially in the developing countries (Rosegrant et al., 2009). Yet, maize yields in many developing countries are severely limited by an array of abiotic and biotic stresses, besides other factors. Production may not be able to meet out the demands without strong technological and policy interventions (Shiferaw et al., 2011). Uncontrolled area expansion cannot be a solution for this, as this could potentially threaten the fragile natural resources, 
including forests and hill slopes in the $\mathrm{f}$ maize is the changing global climate (Cairns et al., 2012). Climate change scenarios indicate that agriculture production will largely be negatively affected and will impede the ability of many regions developing world. Another important challenge that threatens the long-term production growth o to achieve the necessary gains for future food security (Lobell et al., 2008). The diversity of several important crops, including maize, spread across the world is threatened by rapid urbanization and habitat erosion as well as by the unpredictable and extreme climatic events, including increasing frequency of drought, heat and flooding.

Concerted and intensive efforts are required to develop climate-change-resilient maize cultivars while accelerating the yield growth, without which the outcome will be hunger and food insecurity for millions of poor consumers of maize. Our ability to broaden the genetic base of maize and to breed climate-resilient and high yielding cultivars adaptable to diverse agro-ecologies where maize is grown will undoubtedly depend on the efficient and rapid discovery and introgression of novel/ favourable alleles and haplotypes. The enormous genetic diversity in maize, especially in the landraces and the wild relative, teosinte and their need for novel and systematic initiatives to understand and utilize the genetic diversity. The maize landraces are usually genetically heterogeneous populations (each such population comprising a mixture of genotypes), and are typically selected by farmers for better adaptation to specific environment, prolificacy, flowering behaviour, yield, nutritive value and resistance to biotic and abiotic stresses. A maize landrace is mostly defined by the farmer in terms of ear characteristics; the ear type is usually maintained by the farmers through conservative selection in spite of considerable gene flow (Louette et al., 1997; Louette and Smale, 2000). Development of number of modern high yielding hybrids and synthetic varieties in maize has replaced all the elite landraces and has posed a big threat in terms of loss of valuable genetic variability and potential genetic vulnerability. Genetic diversity created in the farmers field over millennia complemented by genetic diversity present in the wild relatives of crop provide the raw material for improving crop productivity through plant breeding. These landrace populations are finite and vulnerable to losses due to development of new crop varieties, growing urbanization, natural hazards etc. These valuable resources contribute enormously towards the millennium development goals of food security, poverty alleviation, environmental protection and sustainable development. In the State Jammu and Kashmir (India), maize crop is second in importance after rice and is a staple food of people living in upper hilly regions. The maize is generally grown as rainfed crop on marginal lands particularly in hilly terrains of the Kashmir valley. Maize is usually harvested at green cob stage and consumed in roasted or boiled form. Besides, the flour is used for making Chapati and is an important source of poultry feed.

Exploitation of heterosis through the development of modern high yielding hybrids and synthetics has gradually replaced the low yielding maize populations at a faster rate in maize growing regions of the world. However, maize hybrids could not become so popular in Kashmir because the hybrids are developed for more favourable environments and add a non-significant gain in performance under the marginal environments. The high seed cost further result in low preference. In some cases diminishing returns were realized because of their poor adaptability under cold temperate conditions of Kashmir. Some land race populations of maize are still popular 
with the farmers of Kashmir. A number of landraces of maize have been documented from Kashmir valley but presently few are under cultivation. Therefore, the present study was undertaken to screen the thirty maize landraces for root traits in relation to draught tolerance.

\section{Materials and Methods}

\section{Screening of maizelandraces for root traits in relation to drought tolerance}

The present study was undertaken during 2017 at Faculty of Agriculture, SKUAST-K at Wadura (34o 17' Northand 74o 33 E at an altitude of $1594 \mathrm{~m}$ amsl). Thirty of maize landraces were used for the present study. The genotypes were evaluated in a controlled atmosphere green house. Seeds were grown in PVC columns of $1.2 \mathrm{~m}$ length and $20 \mathrm{~cm}$ diameter in a medium composed of soil, sand and vermincompost $(2: 2: 1)$. Initially four seeds were grown but later on only one plant per column was maintained. Drought was imposed at four leaf stage.

The irrigated experiment was watered regularly. After 48 days of crop stand, the roots were carefully harvested from columns and were carefully separated from the growing medium without any breakage in the root system. The soil particles and other impurities were removed by immersing the roots in a detergent solution for five minutes and later on rinsed with water. The shoot of each plant was separated by cutting at the base of the stem. After removing shoots, roots were laid on a flat surface and stretched to measure their length (from the base of the stem to the tip of the root system) as an estimate of rooting depth. The roots were also cut into two equal parts to estimate the differential biomass partitioning in top and bottom zones of root. The design was CRD with two replications for each drought and irrigated treatments.

\section{Results and Discussion}

The 30 landraces of maize studied were analyzed in controlled green house facility for rooting depth, root biomass, shoot biomass, shoot height, biomass allocation as well as root volume (Table 1). Rooting depth was highest in SRG $9(47 \mathrm{~cm})$ and lowest in SRG $5(14 \mathrm{~cm})$ under drought condition. Root volume was highest in SRG9, SRG 10, SRG 12, SRG 19 and SRG 26while lowest in SRG5 under drought conditions. The relative proportion of root biomass allocation to the top and bottom zones reveals that highest proportion of roots at bottom under drought was for SRG $21(5 \mathrm{~g})$ while as lowest for SRG $21(0.2 \mathrm{~g})$. Similarly root biomass in top portion was highest under drought for SRG 21 $(9 \mathrm{~g})$ and lowest in SRG 7 (1.1 g).

Huang et al., (2013) reported that deficiencies of soil water resulted in high root: shoot ratio and relatively, more biomass was allocated to the root than to the shoot, and plant allocated more resource to the belowground growth. The same pattern of partitioning has also been observed in other plants by (Gonzales et al., 2008). Beebe et al., (2014) has also reported that deeper roots alone are not sufficient to confer drought resistance if not combined with other traits. Under few conditions these differences can be clearly related to crop performance (Manschadi et al., 2006). Wasson et al., (2012) stated that maximum rooting depth and shifting of rooting density to deeper layers were most relevant root traits for yield under rainfed conditions. 
Table.1 Root and shoot characteristics of land laces under drought conditions

\begin{tabular}{|c|c|c|c|c|}
\hline $\begin{array}{l}\text { Name of the } \\
\text { landrace }\end{array}$ & $\begin{array}{c}\text { Rooting } \\
\text { depth } \\
\text { (cm) }\end{array}$ & $\begin{array}{c}\text { Top } \\
\text { weight } \\
\text { (g) }\end{array}$ & $\begin{array}{c}\text { Bottom weight } \\
\text { (g) }\end{array}$ & $\begin{array}{c}\text { Root } \\
\text { volume }\end{array}$ \\
\hline SRG 1 & 33 & 2.2 & 2 & 8 \\
\hline SRG2 & 28 & 3.4 & 0.3 & 5 \\
\hline SRG3 & 26 & 1.3 & 0.9 & 6 \\
\hline SRG4 & 22 & 1.4 & 0.8 & 5 \\
\hline SRG5 & 14 & 1.2 & 0.4 & 3 \\
\hline SRG6 & 19 & 1.6 & 0.2 & 4 \\
\hline SRG7 & 20 & 1.1 & 0.4 & 9 \\
\hline SRG8 & 41 & 3.7 & 0.3 & 5 \\
\hline SRG9 & 47 & 3.3 & 2.5 & 15 \\
\hline SRG10 & 32 & 6.3 & 0.9 & 15 \\
\hline SRG11 & 24 & 1.4 & .8 & 5 \\
\hline SRG12 & 28 & 2.1 & 1.1 & 15 \\
\hline SRG13 & 26 & 2.6 & 1.1 & 9 \\
\hline SRG14 & 37 & 3.5 & 2.6 & 8 \\
\hline SRGL15 & 20 & 1.8 & 0.6 & 12 \\
\hline SRGL16 & 21 & 2.5 & 1 & 6 \\
\hline SRG17 & 27 & 2.6 & 0.4 & 6 \\
\hline SRG18 & 24 & 4.1 & 1.4 & 6 \\
\hline SRG19 & 25 & 3.8 & 3.5 & 15 \\
\hline SRG20 & 40 & 3.1 & 1.9 & 8 \\
\hline SRG21 & 37 & 9 & 5 & 12 \\
\hline SRG22 & 23 & 1.8 & 1.6 & 6 \\
\hline SRG23 & 19 & 3 & 2.4 & 4 \\
\hline SRG24 & 26 & 3 & 2.6 & 8 \\
\hline SRG25 & 20 & 2.4 & 1 & 4 \\
\hline SRG26 & 31 & 5.4 & 1.8 & 15 \\
\hline SRG27 & 16 & 1.2 & 0.21 & 3 \\
\hline SRG28 & 24 & 3.5 & 1.2 & 9 \\
\hline SRG29 & 34 & 7.6 & 1.2 & 11 \\
\hline SRG30 & 22 & 2.3 & 1 & 4 \\
\hline
\end{tabular}

\section{Acknowledgements}

Authors acknowledge the financial help from PPV\&FRA.

\section{References}

Beebe, S.E. and Smith, C. 2014. Selection for drought tolerance in common beans. Crop Science 48(2): 582-592.

Cairns, J.E., Sonder, K., Zaidi, P.H., Verhulst, N., Mahuku, G., and Babu, R. 2012. Maize production in a changing climate. Adv. Agron. 114:1-58.

FAO, 2010.FAOSTAT. Food and Agriculture Organization of the United Nations 
Gonzales, W.L., Suarez, L.H., MolinaMontenegro, M.A. and Gianoli, E. 2008. Water availability limits tolerance of apical damage in the Chilean tarweed Madiasativa. ActaOecologica, 34(1): 104-110.

Huang, T.K., Han, C.L., Lin, S.I., Chen, Y.J., Tsai, Y.C., Chen, Y.R., Chen, J.W., Lin, W.Y., Chen, P.M., Liu, T.Y. and Chen, Y.S. 2013. Identification of downstream components of ubiquitin-conjugating enzyme PHOSPHATE2 by quantitative membrane proteomics in Arabidopsis roots. The Plant Cell, 25(10): 40444060.

Lobell, D. B., Burke, M. B., Tebaldi, C., Mastrandrea, M. M., Falcon, W. P. and Naylor, R. L. (2008). Prioritizing climate change adaptation needs for food security in 2030. Science 319: 607 -610 .

Louette, D., Charrier, A., Berthaud, J. 1997) In situ conservation of maize in Mexico: genetic diversity and maize seed management in a traditional community. Econ Bot 51: 20-38

Louette, D. and Smale, M. 2000.Farmers' seed selection practices and traditional maize varieties

Cuzalapa,
Mexico. Euphytica 113: 25-41

Manschadi, A.M., Christopher, J. and Hammer, G.L. 2006. The role of root architectural traits in adaptation of wheat to water-limited environments. Functional Plant Biology 33(9): 823837.

Rosegrant, M., W. et al., 2009. Looking into the future for agriculture and AKST (Agricultural Knowledge Science and Technology). In Agriculture at a crossroads (eds McIntyre B. D., Herren H. R., Wakhungu J., Watson R. T.), pp. 307-376 Washington, DC: Island Press

Shiferaw, B., Prasanna, B., Hellin, J., and Bänziger, M. 2011. Crops that feed the world 6. Past successes and future challenges to the role played by maize in global food security. Food Security. 3: 307-327.

Wasson, A.P., Richards, R.A., Chatrath, R., Misra, S.C., Prasad, S.S., Rebetzke, G.J., Kirkegaard, J.A., Christopher, J. and Watt, M. 2012. Traits and selection strategies to improve root systems and water uptake in water-limited wheat crops. Journal of Experimental Botany. 63(9): 3485-3498.

\section{How to cite this article:}

Sapna, Z. A. Dar, Sherry Jacob, A. A. Lone and Rasool, F. 2020. Screening of Root Traits in Maize (Zea mays L.) Landraces in Relation to Drought Stress. Int.J.Curr.Microbiol.App.Sci. 9(05): 3034-3038. doi: https://doi.org/10.20546/ijcmas.2020.905.361 